Purwohawati Yuliana, Postgraduate Student, Faculty of Economy, Sriwijaya University, Palembang,

ORCID ID: 0000-0002-1401-7693

e-mail: yulianapurwohawati@gmail.com

Robiani Bernadette, Professor of Economics, Lecturer at Faculty Economy, Sriwijaya University, Palembang, Indonesia

ORCID ID: 0000-0002-9098-4319

e-mail: bernadetterobiani64@yahoo.co.id

Meutia Inten, Doctor of Economics, Lecturer at Faculty Economy, Muhammadiyah Palembang University, Palembang, Indonesia

ORCID ID: 0000-0002-2418-0283

e-mail: inten26@yahoo.com

\title{
Green Accounting Practice on Corporate Performances
}

Abstract. Introduction. The low awareness of the industry in the application of the green industry through green accounting because when viewed in general as 2 sides of a coin, on the one side will bring benefits to the industry but on the other hand as if it would lead to the potential for increased costs, through environmental costs. The population is 184 industrial companies both state-owned enterprises and public companies. The sampling technique uses purposive sampling so that the samples obtained are 18 public companies. The data used in this study are historical data, such as financial data, earnings per share data and stock valuation in companies that apply green accounting and listings on the Indonesia Stock Exchange.

Purpose. The purpose of this study is to determine the effect on earnings per share and stock valuation before and after the adoption of green accounting.

Results. The results of the study concluded that there are significant differences and a positive effect between earnings before the application of green accounting and earnings after the application of green accounting. For the application of green accounting on stock price there is no significant difference between the stock price before and stock valuation after the adoption of green accounting, because there are three publicly traded companies that sell initial shares (IPOs) at the time of applying green accounting.

Conclusions. There are significant differences and a positive effect between earnings before the application of green accounting and earnings after the application of green accounting. For the application of green accounting on stock price there is no significant difference between the stock price before and stock valuation after the adoption of green accounting.

Keywords: earnings per share; stock valuation; green accounting; company performance.

\section{Удк 332.1} Індонезія

Пурвохаваті Юліана, аспірант, факультет економіки, Університет Шривіджая, Палембанг,

Робіані Бернадетте, професор факультету економіки, Університет Шривіджая, Палембанг, Індонезія

Меутіа Інтен, доктор економічних наук, викладач факультету економіки, Університет Мухаммадіях Палембанг, Палембанг, Індонезія

\section{Практичні аспекти екологічного обліку корпоративних результатів}

Анотація. Встановлено, що екологічного обліку застосовується недостатньо, оскільки підприємства найчастіше розглядають його впровадження з двох сторін: по-перше, це принесе користь галузі, але по-друге, підвищить суму витрат за рахунок екологічних витрат. Сукупність вибірки у статті становить 184 промислові компанії, серед яких як державні підприємства, так і публічні компанії. Методика вибірки базувалася на цілеспрямованій вибірці таким чином, що до неї увійшли 18 публічних компаній. Дані, використані в дослідженні, $\epsilon$ історичними даними, зокрема - фінансові дані, дані про прибуток на акцію та оцінка запасів у компаніях, які застосовують екологічний облік та котируються на Індонезійській фондовій біржі.

Метою дослідження є визначення впливу застосування екологічного обліку на прибуток на акцію та оцінку запасів (до та після його впровадження) на різних суб'єктах господарювання.

Результати дослідження свідчать, що існують суттєві відмінності та позитивний ефект між доходами до застосування екологічного обліку та доходами після його застосування. Вивчаючи вплив екологічного обліку за ціною акцій встановлено, що не існує суттєвої різниці між ціною акцій до і оцінкою акцій після його впровадження, оскільки

Стаття надійшла до редакції: 05.07.2020

Received: 05 July 2020 
на момент застосування екологічного обліку функціонують три публічні торгівельні компанії, які продають первинні акції (IPOs).

Таким чином, встановлено суттєві відмінності та позитивний ефект між прибутками до застосування екологічного обліку та прибутками після його застосування. При цьому встановлено, що, на наше переконання, не існує суттєвої різниці між ціною акцій до і оцінкою акцій після впровадження екологічного обліку.

Ключові слова: прибуток на акцію, оцінка запасів, екологічний облік, продуктивність компанії.

Formulation of the problem. The concept of green accounting has actually begun to develop since the 1970s in Europe. As a result of pressure from non-government institutions and increased environmental awareness among the public, the company is urging that companies not only engage in industrial activities for business purposes, but also implement environmental management. The aim is to improve the efficiency of environmental management by evaluating environmental activities from the perspective of environmental costs and economic benefits, then produce environmental protection effects [1].

Green Accounting focuses on accounting treatment and reporting information on the sacrifice of corporate economic assets for the cost of social and environmental responsibility. Recording and disclosure will further reduce information asymmetry between the company and its stakeholders including the local society [2].

With the smaller level of information asymmetry, this will create stakeholders trust in the company, by accepting the company's products, customer loyalty, and increasing investment, so that these trusts will increase earnings per share and stock prices.

In Indonesia, the government has begun to encourage industry to implement green industry practices since 2010. One form of government effort is to give awards to industries that run green industry practices. Enhancement of industries that have voluntarily participated in green industry assessments by the government has taken place from year to year. The low awareness of the industry in the application of the green industry through green accounting because when viewed in general as 2 sides of a coin, on the one side will bring benefits to the industry but on the other side as if it would lead to the potential for increased costs, through environmental costs. This is makes not many companies apply green accounting. If it analyze deeper, for a longer period of time, the application of green accounting will be very beneficial for all parties, both entrepreneurs, consumers and other stakeholders (investors, the public). The sacrifice of companies in issuing costs to the environment can reduce the potential expenditure of greater costs in the future such as the cost of community demands for environmental damage by industry, the risk of business closure due to government sanctions and so forth.

To further strengthen the results of this study the result compared to previous studies. This study also examines earnings per share and stock valuation that do not win green industry awards. Based on the explanation above, the writer is interested in conducting research with the title green accounting practice on corporate performances.
Analysis of recent research and publications. A sign or signal is an action taken by a company to give instructions to investors about how management views the company's prospects [3]. This signal is in the form of information about what has been done by management to realize the wishes of the owner. The impetus of the company to provide information because there is asymmetry of information between the company and external parties, because the company knows more about the company and prospects to come than external parties (investors and creditors). Lack of information for external parties about the company causes them to protect themselves by giving low prices to the company. Companies can increase company value by reducing information asymmetry.

One way to reduce information asymmetry is to provide signals to external parties. Signal theory or signaling theory is the impact of the information asymmetry. Signal Theory is a theory that explains how corporate signals are given to parties that concerned with that information [4]. Signaling theory is closely related to the availability of information. Financial statements can be used to make decisions for investors, and financial statements are the most important part of the company's fundamental analysis. The use of signal theory is to provide information in the form of earnings per share and stock prices changes. Thus, this information will be a good signal for investors. Because with a high level of earnings per share shows the company's performance is good, then investors will be interested in investing their funds in the form of securities or shares.

Green Accounting or commonly referred to environmental accounting, according to the AICPA (American Institute of Certified Public Accounting, 1998) in its bulletin, Accounting is defined as accounting is the art of recording, classifying and summarizing in a significant manner and in the terms of money, transactions and events which are and part, at least of financial character and interpreting the result there of. Environmental accounting is a term relating to the inclusion of environmental costs in the accounting practices of companies or government institutions. Environmental costs are impacts arising from financial and non-financial aspects which must be borne as a result of activities that affect environmental quality [5]. Green Accounting or often also referred to as environmental accounting is the practice of incorporating the principles of environmental management and conservation into reporting practices that include analysis of costs and benefits [6]. Green Accounting is a contemporary concept in accounting that supports the green movement of business entities in which it identifies, measures, 
evaluates, and discloses costs associated with corporate activities related to the environment [7].

The basics of policy on the environment in Indonesia began since the enactment of the environmental law in 1982. In the field of Accounting in 1994, the Indonesian Accounting Association (IAI) which then set a standard for environmental accounting disclosure in the Financial Accounting Standards Agreement (PSAK) No. 32 concerning development accounting and SFAS No. 33 regarding general mining accounting, in its development. Hadjoh \& Sukarta (2012) in their research found that company size and company financial performance had a positive effect on the level of environmental accounting complaints. Saymeh \& Shoubaqi (2015) show that the thinking and acting of professionals in accounting is still very low in terms of responsibility for environmental preservation. While the research of previous researcher shows the level of social disclosure in Indonesia is still relatively low at $42.32 \%$. In Indonesia, the application of environmental performance assessment of the achievements of companies participating in the Company Performance Rating Assessment Program in Environmental Management (PROPER), the instrument used by the Ministry of Environment to assess and rank companies in improving their environment [10], [11].

Company performance is the result of business processes in which the sacrifice of various kinds of resources that can be human resources and corporate finance [12]. When the company increases, it can be seen from the company's activities in order to generate maximum profits. Companies can also use financial information or also use non-financial information. This non-financial information can contain customer satisfaction with services provided by the company. Even so, most companies judge by financial ratios in certain periods [13].
Earning per Share (EPS) growth is an important measure of a company's performance because it shows how much money the company is making for its shareholders. And not only because of changes in profits but also after all the effects of the issuance of new shares. Earning Per Share (EPS) is the company's ability to distribute the income obtained to its shareholders. The higher the company's ability to distribute income to its shareholders, reflects the greater success of the business [14]. The price of shares is formed in the capital market and is determined by several factors such as earnings per share or earnings per share, the ratio of earnings to prices per share or price earning ratio, the risk-free interest rate measured by the interest rate on deposits the government and the level of certainty of the company's operations [15].

Indonesia is a developing country and research in developing countries has been carried out, with the research title "Green Accounting and Management for Sustainable Manufacturing in Developing Countries". This study analyzes sustainable environmental accounting in developing countries and the results of the study explain that motivation in developing countries is different from developed countries in implementing sustainable social and environmental accounting [16].

Formulation of research goals. The purpose of this study is to determine the effect on earnings per share and stock valuation before and after the adoption of green accounting. The low awareness of the industry in the application of the green industry through green accounting because when viewed in general as 2 sides of a coin, on the one side will bring benefits to the industry but on the other hand as if it would lead to the potential for increased costs, through environmental costs.

Outline of the main research material. This research is formulated in the framework of the picture as follows:

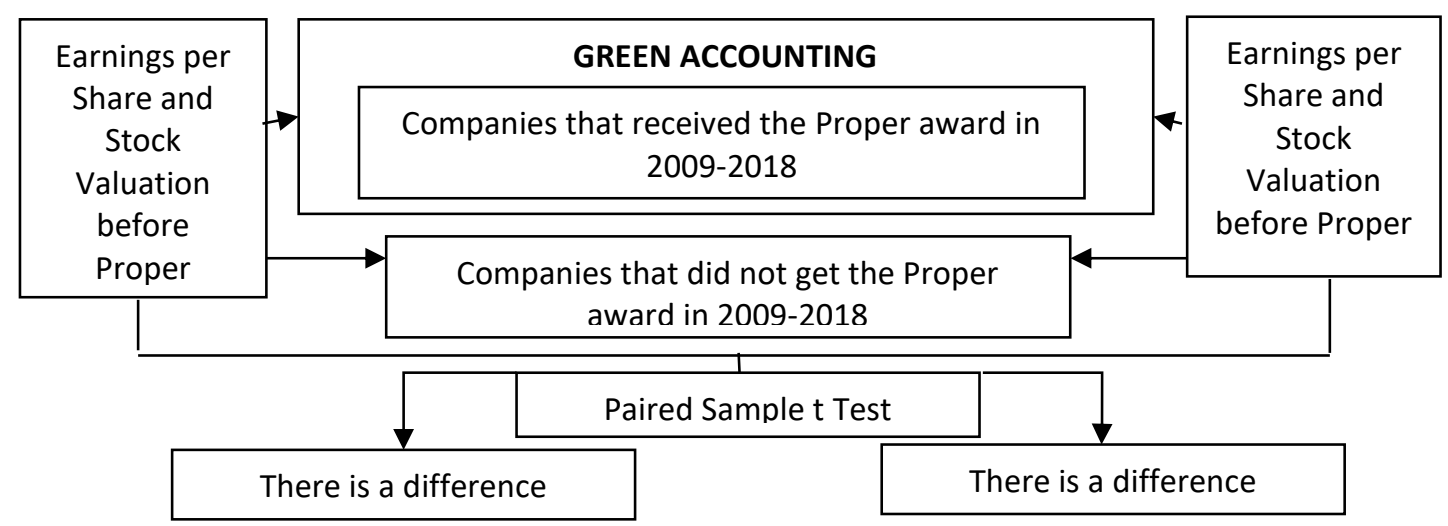

Figure 1. Conceptual Framework

Source: Data process, 2020.

Research hypothesis of this article:

1. $\mathrm{H} 1$ = there are differences in earnings per share before and after implementation green accounting
2. $\mathrm{H} 2$ = there are differences in the growth of stock prices before and after the application of green accounting.

The year of observation was 10 ten years, the period of 2009 - 2018. The number of companies that 
participated in PROPER was 184 companies consisting of various state-owned companies and public companies.

The sampling technique used purposive sampling so that the samples obtained are 18 companies that go public or are listed on the Indonesia Stock Exchange and receive the gold and green PROPER award. The data used in this study are historical data, such as financial data, earnings per share data and stock valuation in companies that apply green accounting on the listings of he Indonesia Stock Exchange. Testing this hypothesis is by using paired t-test (paired sample test).

By using the Kolmogorov Smirnov Test, an absolute value of 0.172 is obtained with a significance value of 0.170 for data prior to the application of green accounting, while for data after the application of green accounting an absolute value of 0.189 is obtained with a significance value of 0.088 . Provided that if $p$-value (significance) $>0.05$, the data is normally distributed, and it can be concluded that earning data before and after the application of green accounting is stated to be normally distributed, so that statistical parametric testing can be used. For stock price data normality test has absolute value of 0.135 is obtained with a significance value of 0.200 for data before applying green accounting, whereas for data after applying green accounting an absolute value of 0.213 is obtained with a significance value of 0.030 . With the provision that if $p$-value (significance) $>0.05$, then the normal distribution, it can be concluded that the stock price data prior to the application of green accounting is stated normally distributed. Paired sample ttest earning test results shows on table 1.

Table 1 Paired Sample T-Test Earning Test Results

\begin{tabular}{|c|c|c|c|c|c|c|c|c|c|}
\hline \multicolumn{9}{|c|}{ Paired Samples Statistics } & \\
\hline & & & \multicolumn{2}{|l|}{ Mean } & $\mathrm{N}$ & Std. Deviation & \multicolumn{2}{|c|}{$\begin{array}{l}\text { Std. Error } \\
\text { Mean }\end{array}$} & \\
\hline \multirow{4}{*}{$\begin{array}{c}\text { Pair } \\
1\end{array}$} & \multicolumn{2}{|c|}{ Earning before } & \multirow{2}{*}{\multicolumn{2}{|c|}{16.394 .444}} & \multirow[t]{2}{*}{18} & \multirow[t]{2}{*}{174.750 .233} & \multirow{2}{*}{\multicolumn{2}{|c|}{41.189 .025}} & \\
\hline & \multicolumn{2}{|c|}{ Green Accounting } & & & & & & & \\
\hline & \multicolumn{2}{|c|}{ Earning after } & \multirow[t]{2}{*}{28.954 .444} & \multirow{2}{*}{\multicolumn{2}{|c|}{18}} & \multirow[t]{2}{*}{ 274.722.179 } & \multirow{2}{*}{\multicolumn{2}{|c|}{64.752 .639}} & \\
\hline & \multicolumn{2}{|c|}{ Green Accounting } & & & & & & & \\
\hline \multicolumn{7}{|c|}{ Paired Samples Correlations } & & & \\
\hline & & & $\mathrm{N}$ & \multicolumn{2}{|c|}{ Correlation } & Sig. & & & \\
\hline \multirow[t]{2}{*}{$\begin{array}{c}\text { Pair } \\
1\end{array}$} & \multicolumn{2}{|c|}{$\begin{array}{c}\text { Earning before Green } \\
\text { Accounting }\end{array}$} & \multirow{2}{*}{\multicolumn{2}{|c|}{18}} & \multirow[t]{2}{*}{,766 } & \multirow[t]{2}{*}{,000 } & & & \\
\hline & \multicolumn{2}{|c|}{$\begin{array}{l}\text { Earning after Green } \\
\text { Accounting }\end{array}$} & & & & & & & \\
\hline \multicolumn{10}{|c|}{ Paired Samples Test } \\
\hline & & \multicolumn{5}{|c|}{ Paired Differences } & \multirow[t]{3}{*}{$\mathrm{T}$} & \multirow[t]{3}{*}{$\mathrm{Df}$} & \multirow{3}{*}{$\begin{array}{l}\text { Sig. (2- } \\
\text { tailed) }\end{array}$} \\
\hline & & \multirow[t]{2}{*}{ Mean } & $\begin{array}{c}\text { Std. } \\
\text { Deviation }\end{array}$ & \multirow[t]{2}{*}{$\begin{array}{l}\text { Std. Error } \\
\text { Mean }\end{array}$} & \multicolumn{2}{|c|}{$\begin{array}{l}\text { 95\% Confidence Interval of } \\
\text { the Difference }\end{array}$} & & & \\
\hline & & & & & Lower & Upper & & & \\
\hline \multirow[t]{4}{*}{$\begin{array}{c}\text { Pair } \\
1\end{array}$} & $\begin{array}{l}\text { Earning } \\
\text { before } \\
\text { Green }\end{array}$ & \multirow[t]{4}{*}{$\begin{array}{c}- \\
125.600 .000\end{array}$} & 180.277 .117 & 42.491 .724 & $\begin{array}{c}- \\
215.249 .701\end{array}$ & $\begin{array}{c}- \\
35.950 .299\end{array}$ & $\begin{array}{c}- \\
2.956\end{array}$ & 17 & 0,009 \\
\hline & Accounting & & & & & & & & \\
\hline & $\begin{array}{l}\text { Earning after } \\
\text { Green }\end{array}$ & & & & & & & & \\
\hline & Accounting & & & & & & & & \\
\hline
\end{tabular}

Source: Processed by the writer, 2020

There is an increase in earnings after the application of Green Accounting, which is the average earnings before the application of green accounting is 1639 and after the application of green accounting is 2895 . The correlation test results show a strong correlation, which is indicated by the correlation number 0.766 meaning there is a strong correlation between the application of green accounting with earnings. And the significance value of this correlation test is $0,000<0.05$, meaning that there is a significant difference between earnings before applying green accounting and after applying green accounting. If seen from paired sample t-test, it is known that $t$ arithmetic is 2.956 while $t$ table for $n=18$ with a 95\% confidence level is 2.152 meaning $t$ arithmetic $>t$ table so that $\mathrm{Ho}$ is rejected and $\mathrm{H} 1$ is accepted, so it is concluded that there are significant differences between earnings before applying green accounting to earnings growth after applying green accounting. While the results of the paired sample t-test obtained significance values $0.009<0.05$, which also means that there are significant differences between earnings before and after applying green accounting. 
Електронне наукове фахове видання з економічних наук “Modern Economics», №22 (2020), 84-89 https://modecon.mnau.edu.ua | ISSN 2521-6392

Table 2 Paired Sample T-Test Stock Price Test Results

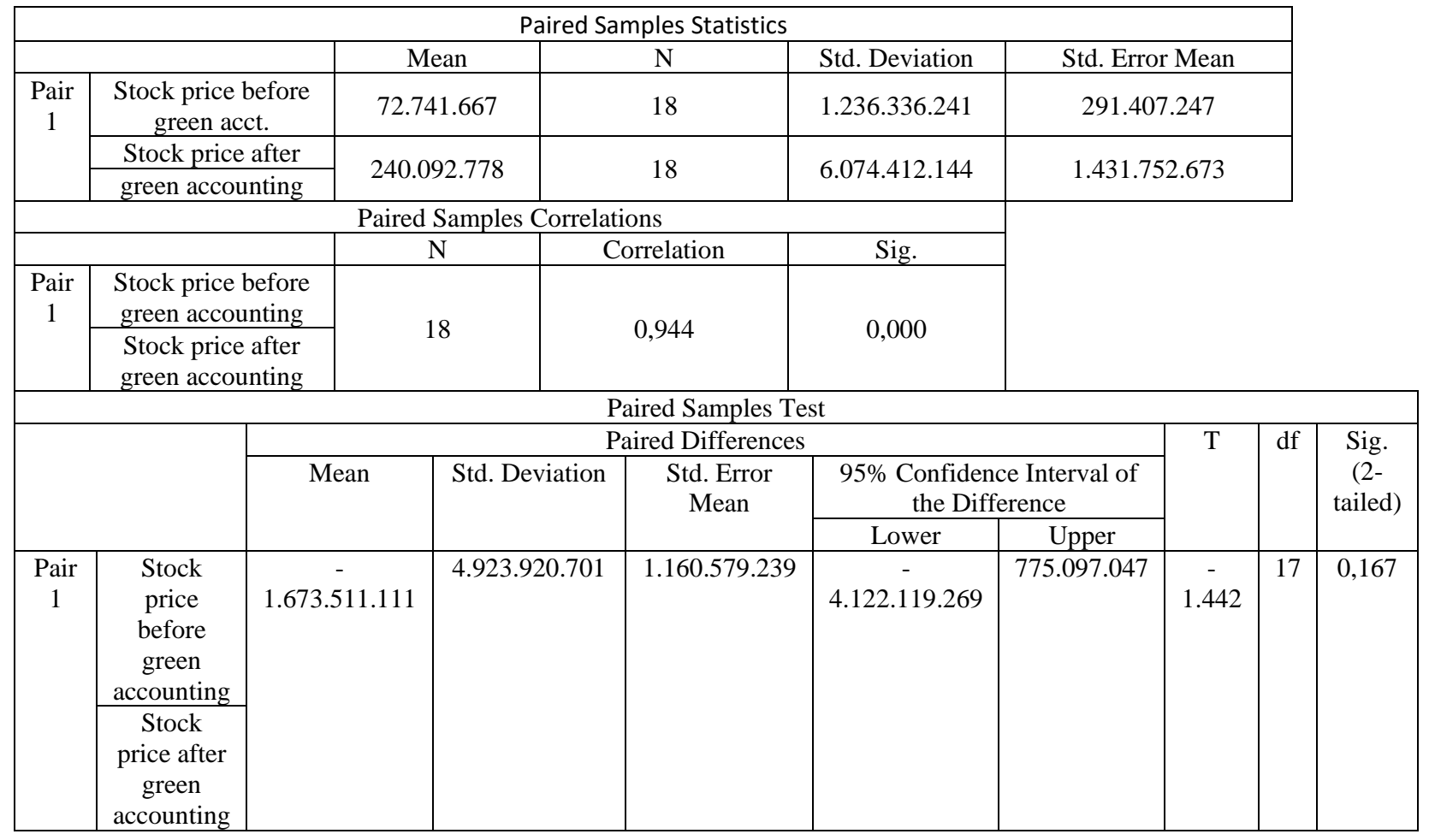

Source: Processed by the writer, 2020

There is an increase in the average stock price after the adoption of green accounting that is the average stock price before the implementation of green accounting is 7274 and after the application of green accounting is 24009. The correlation test results show a strong correlation shown by the correlation number 0.944 means that there is a correlation strong application of green accounting with stock prices. However, if seen from paired sample t-test in the above table, it is known that $t$ count is 1,442 while $t$ table $n=18$ with a $95 \%$ confidence level is 41,221 means that $t$ count $<t$ table so that Ho is accepted and $\mathrm{H} 1$ is rejected, so it is concluded that it is not there is a significant difference between the stock price before the adoption of green accounting with the growth of the stock price after the adoption of green accounting, even though when viewed from the test results there is a significant increase or difference between the stock price before and after the adoption of green accounting.

Correlation test for effect of green accounting application on earning per share shows that there is a strong correlation, indicated by the correlation number 0.766 , which means there is a strong correlation between the application of green accounting with earnings. And the significance value of this correlation test is $0,000<0.05$, meaning that there is a significant difference between earnings before applying green accounting and after applying green accounting. By seeing an increase in earnings per share in the company's annual report proves that it gives a positive signal to investors so that the company's development will avoid future obligations.
There are 3 (three) public companies that have just sold their first shares or IPO on the Indonesia Stock Exchange and have applied green accounting, and received a Proper rating. Example: PT. Kalbe Farma, Tbk did an IPO in 2013. PT. Sido Muncul, Tbk Herbal and Pharmaceutical Industry conducted an IPO in 2013, PT. Phapros, Tbk conducted an IPO in 2018. This study uses stock price data from 2009 to 2018, as well as the split point for the paired sample t-test in 2007 . So when doing an IPO in 2013 and 2018, it was very influential. in data processing in 2007 and 2008 as a break point and hypothesis testing, which initially had a strong correlation but there was no significant difference between the stock price before and after the adoption of green accounting.

Based on the results of the analysis and testing of the application of green accounting to company performance on companies listed on the Indonesia Stock Exchange and who have received the Proper award in 2009 to 2018, it can be concluded that there is a significant difference and positive effect between earnings before applying green accounting and earnings after applying green accounting. This can also be seen from the average earnings that continue to increase. For the application of green accounting on stock prices there is no significant difference between the stock price before and the growth of stock prices after the adoption of green accounting, because there are three publicly traded companies that sell initial shares (IPOs) at the time of applying green accounting.

Conclusions. Based on the results of the analysis and testing of the application of green accounting to company 
performance on companies listed on the Indonesia Stock Exchange and who have received the Proper award in 2009 to 2018 , it can be concluded that there is a significant difference and positive effect between earnings before applying green accounting and earnings after applying green accounting. This can also be seen from the average earnings that continue to increase. For the application of green accounting on stock prices there is no significant difference between the stock price before and the growth of stock prices after the adoption of green accounting, because there are three publicly traded companies that sell initial shares (IPOs) when implementing green accounting.

\section{References:}

1. Astuti, N. \& Susilo, J. (2014). Penyusunan Model Green Accounting Untuk Perusahaan Melalui Perhatian, Keterlibatan, Pelaporan Akuntansi Lingkungan Dan Auditnya. Permana, 5(2), 17-32.

2. Ratna, S. M. (2016). Dampak Green Accounting terhadap Kinerja Keuangan.

3. Brigham, E. F. \& Houston, J. F. (2010). Manajemen Keuangan (Buku 1) (Edisi 8), no. Buku 1, 628.

4. Noor (2015). Pengaruh Return on Assets Leverage, Corporate Governance dan Sites Growth terhadap Tax Efficience pada Perusahaan Manufaktur di Bursa Efek Indonesia.

5. Ikhsan, A. (2008). Pengenalan Akuntansi Lingkungan.

6. Hidayat, M. (2016). Perkembangan Green Accounting Dan Penerapannya Dalam Menjawab Permasalahan Lingkungan Di Indonesia, 53(9), 1689-1699. doi: 10.1017/CBO9781107415324.004.

7. Lako, A. (2016). Transformasi Menuju Akuntansi Hijau. PA Indones., no. December, 52-54.

8. Hadjoh and Sukarta (2012). Pengaruh Ukuran Perusahaan, Kinerja Keuangan dan Eksposur Media opada Pengungkapan Informasi Lingkungan.

9. Saymeh and A. Shoubaqi (2015). Perceptions of Environmental Accounting in the Jordanian Pharmaceutical Industries.

10. Henny and Murtanto (2001). Analisis Pengungkapan Sosial pada Laporan Tahunan. Media Ris. Akuntansi, Audit. dan Inf., 1.

11. Sugiyono (2014). Metode Penelitian Kuantitatif Kualitatif dan $R \& D$, Cetakan ke. Bandung: Alfabeta Bandung

12. Moerdiyanto (2010). Pengaruh tingkat pendidikan manajer terhadap kinerja perusahaan. Cakrawala Pendidik, 1, 2-3.

13. Chariri and Ghozali (2008). Teori Akuntansi.

14. Kasmir (2014). Analisa Laporan Keuangan. PT. Raja Grafindo Persada,.

15. Sartono (2001). Manajemen Keuangan Teori dan Aplikasi. Yogyakarta BPEF.

16. Sherine, C. \& Jacob, J. (2012). Green Accounting and Management for Sustainable Manufacturing in Developing Countries," Int. J. Bus. Manag., 7(20), 36-43. doi: 10.5539/ijbm.v7n20p36.

Ця робота ліцензована Creative Commons Attribution 4.0 International License 